УДК 164:005.932.5-048.34

DOI: $10.15673 /$ fie.v12i3.1815

\author{
Савенко І.І. \\ доктор економічних наук, профресор \\ кафедра менеджменту і логістики \\ E-mail: iisavenko52@ ukr.net \\ ORCID ID: 0000-0001-7901-6360 \\ Седіков Д.В. \\ аспірант \\ кафедра менеджменту та логістики \\ Одеська національна академія харчових технологій \\ вул. Канатна, 112, м. Одеса, Україна, 65039 \\ E-mail: sedikov94@ukr.net \\ ORCID ID: 0000-0001-7706-2881
}

\title{
ЛОГІСТИЧНИЙ МЕНЕДЖМЕНТ, ЯК ІНСТРУМЕНТ ОПТИМІЗАЦІЇ ЛОГІСТИЧНИХ ВИТРАТ
}

Конкурентоспроможність підприємств виступає ключовою умовою виживання та подальшого їх розвитку в умовах жорсткої ринкової економіки. Забезпечення ефективного рівня конкурентоспроможності досягається різними методами, прийомами організаційного, технологічного та технічного характеру. В переліку ефективних методів та прийомів чільне місце займає логістика, як прогресивний напрямок господарювання. Стаття присвячена дослідженню впливу логістики на конкурентоспроможність підприємств, впливу логістичного менеджменту, як інструментарію логістики, на оптимізацію логістичних витрат, впливу логістичних витрат на формування собівартості продукції та шляхів їх скорочення. Не зважаючи на трансформації, які протікають в суспільстві (перехід до постіндустріалізму), більш ефективних інструментів менеджменту підприємств аніж логістичний підхід, наука та практика не розробила. В роботі проведено дослідження дефініцій «логістика», «логістичний менеджмент», «логістичні витрати» та наведено авторські визначення термінів.

Ключові слова: логістика, логістичний менеджмент, логістичні витрати, функціональні області логістики.

This work is licensed under a Creative Commons Attribution 4.0 International License http://creativecommons.org/licenses/by/4.0/

Постановка проблеми та її зв'язок з важливими науковими та практичними завданнями. Перехід України від планової моделі господарювання до ринкової, змусив підприємців та бізнесменів поновому здійснювати управління підприємствами, означивши їх головною ціллю конкурентоспроможність вироблених товарів та підприємства в цілому. Якість та ціна - основні критерії визначення конкурентоспроможності товарів. Процес досягнення конкурентних рівнів якості та ціни забезпечується певними методами оптимізації. Оптимумом для якості виступає максимальним значення, та мінімальним для ціни. Досягнення означених оптимумів вимагає від керівників усіх рівнів підприємств удосконалювати неефективні структури, постійно здійснювати моніторинг інновацій галузі та запроваджувати їх, що дає можливість бути лідером галузі. Одним із шляхів до лідерства виступає логістичний підхід в господарювання. Дослідження даної роботи присвячено логістичному менеджменту, як інструменту оптимізації логістичних витрат - важливої складової собівартості виробленої продукції.
Аналіз останніх публікацій по проблемі. Перехід від централізованого забезпечення підприємств та галузей матеріально-технічними ресурсами до ринкового механізму логістики, поставив перед практиками та науковцями широке коло питань щодо якісного та безперебійного забезпечення підприємств необхідною сировиною, матеріалами, комплектуючими виробами.

Відсутність практичного досвіду, нової системи 3 логістичного забезпечення, теоретичних та методичних розробок щодо логістичного підходу в матеріально-технічному забезпеченні, викликало створення Української асоціації з логістики, розвиток наукових шкіл, започаткування у закладах вищої освіти кафедр 3 підготовки менеджерів 3 логістики, проведення практичних семінарів та наукових конференцій.

Тематиці управління логістичними витратами в діяльності підприємств присвячені наукові розробки вітчизняних та закордонних вчених Анікіна Б., Бажина I., Бауерокс Д. Дж, Гаджинського А., Клосс Д Дж., Крикавського Є, Касьяна Л., Колодки Я., Лепейка Т., Пономаренка В, Седікової І., Сергеєва В., 
Сумець О, Смирнова I., В. К. Танькова, Чухрай Н. та інших.

Втім, враховуючи значний вплив логістичних витрат на формування конкурентоспроможності підприємств, постає питання дослідження та розробки інструментарію оптимізації означених витрат

Формування цілей дослідження. Ціллю наукової статті виступає дослідження «логістичного менеджменту», як інструментарію оптимізації логістичних витрат.

3 моменту переходу до ринкової моделі управління національною економікою пройшло біля 30 років, що дає можливість підвести певні результати в досягненнях практичної та науково-методичної складових логістики, означити недоліки та визначити шляхи їх усунення чи пом'якшення.

В статті поставлені завдання дослідити сутність понять: логістика; логістичний менеджмент; логістичні витрати; шляхи оптимізації логістичних витрат підприємства.

Виклад основних результатів та їх обгрунтування. Розвиток ефективного підходу до управління потоковими процесами підприємств забезпечується логістикою. На підтримку бізнесу та наукового супроводу 3 розвитку логістики започатковано ряд міжнародних логістичних асоціацій, які представляють різні функціональні області логістики та сфери національних економік.

В Україні діє Українська логістична асоціація, в Свропі - Свропейська логістична асоціація.

До складу закордонних асоціацій, які основою діяльності визначають управління ланцюгами постачань можна віднести:

- Американське товариство контролю за виробництвом та запасами (American Production and Inventory Control Society);

- не прибуткова професійна організація «Інститут управління постачанням» (National Association of Educational ProcurementP);

- Асоціація управління ресурсами та матеріалами охорони здоров'я (Association for Healthcare Resource \& Materials Management).

Серед професійних асоціацій, які надають освітні послуги 3 розвитку персоналу з управління ланцюгами постачань необхідно виділити:

- Рада професіоналів управління ланцюгами поставок (Council of Supply Chain Management Professionals), у 2020 р. відкрила представництво в Україні.

- Міжнародне товариство логістики (International Society of Logistics).

Міжнародна асоціація логістики складів (International Warehouse Logistics Association) займається питаннями управління складськими ресурсами логістичних операторів, вантажовідправників і 3PLспоживачів.

Асоціація логістики та транспорту Північної Америки (Logistics \& Transportation Association of North America) - організація транспортної логістики в США та Канаді [1].

Проведений аналіз широкого кола визначень, як функціонального та широкого значення трактування дефініції «логістика», дав змогу виокремити найбільш вживані. Б. Анікін вважає, що логістика це «наука управління матеріальними потоками від первинного джерела до кінцевого споживача 3 мінімальними витратами, пов'язаними з рухом товарів і потоком інформації, що їх обслуговує» [2]. 3 погляду I. Бажина відносно дефініції логістика наступна «наука про потокові процеси цілеспрямованої людської діяльності. Іншими словами, областю застосування логістики є діяльність людей, спрямована на досягнення певної цілі в будь-якій предметній області, яку можна представити у вигляді потокових процесів» [3].

А. Гаджинський вважає логістика «міждисциплінарний науковий напрямок, безпосередньо пов'язаний з пошуком нових можливостей підвищення ефективності матеріальних потоків» [4]. Згідно визначення В. Сергєєва ще «інтегральний інструмент менеджменту, що сприяє досягненню стратегічних, тактичних або оперативних цілей організації бізнесу за рахунок ефективного з погляду зниження загальних витрат і задоволення вимог кінцевих споживачів щодо якості продукції і послуг р управління матеріальними i/або сервісними потокам , сукупними їм потоками інформації і фінансових коштів» [5]. І. Седікова визначає логістику як «практичну діяльність 3 цілепокладання, прогнозування, планування, організації і контролю процесів руху інтегрованих потоків у ринковій системі...» [6].

Рада логістичного менеджменту США надала два визначення терміну логістика які є найбільш визнаним серед фахівців $з$ логістики:

- у редакції 1985 р. «логістика є процесом планування, управління і контролю ефективного (3 точки зору зниження витрат) потоку запасів сировини, матеріалів, незавершеного виробництва, готової продукції, послуг і супутньої інформації від місця виникнення цього потоку до місця його споживання...для цілей повного задоволення потреб споживачів»;

- у редакції 1998 р. «логістика - це частина процесу в ланцюгах поставок, в ході якого планують, реалізують і контролюють ефективний і продуктивний потік товарів, їх запаси, сервіс і пов'язана інформація від точки їх зародження до точки поглинання (споживання) 3 метою задоволення вимог споживачів». [7]. У визначенні 1998 р. введено поняття ланцюг поставок та указано що логістика виступає частиною даного процесу. Характерним у визначеннях $є$ акцентування на ефективність операцій у ході управління потоками.

Свропейська логістична асоціація (European Logistics Association - ELA) сформулювала таке визначення «логістика - поняття, що охоплює організацію, планування , контроль і реалізацію переміщення товарів від їх проходження (створення, придбання) через виробництво і дистрибуцію до кінцевого споживача 3 метою задоволення вимог ринку за мінімальних витрат і мінімальних капіталовкладень [8].

Узагальнюючи дефініції «логістика», надамо авторське бачення трактуванню поняття «логістика». 
Логістика - це науково-практичний напрям господарювання, сутність якого полягає в забезпеченні логістичних систем необхідними ресурсами за умов оптимізації витрат процесу переміщення ресурсних потоків у межах означених систем.

Незважаючи на різноплановість задач в межах функціональних областей логістики, їх вирішення забезпечується універсальними методами логістики. Базисом сучасної теорії логістики є системний аналіз, кібернетичний підхід, дослідження операцій, прогнозування. Науковою базою логістики виступають:

- математика та теорія ймовірності (теорії випадкових процесів, оптимізації матриць, математична статистика, функціональний аналіз);
- дослідження операцій (лінійне, нелінійне, динамічне програмування, теорії ігор та масового обслуговування, управління запасами, методи імітаційного моделювання та мережевого планування).

- технічна кібернетика (теорії великих чисел, управління, автоматичного регулювання, графів, прогнозування);

- економіка (прогнозування, маркетинг, менеджмент, операційний менеджмент, інвестиційний та інноваційний менеджмент, стратегічне управління, бухгалтерський облік, управління проектами).

Система менеджменту підприємства являє собою композицію функціонально-зорієнтованими сфер діяльності, об'єднаних соціально-економічними цілями (рис 1).

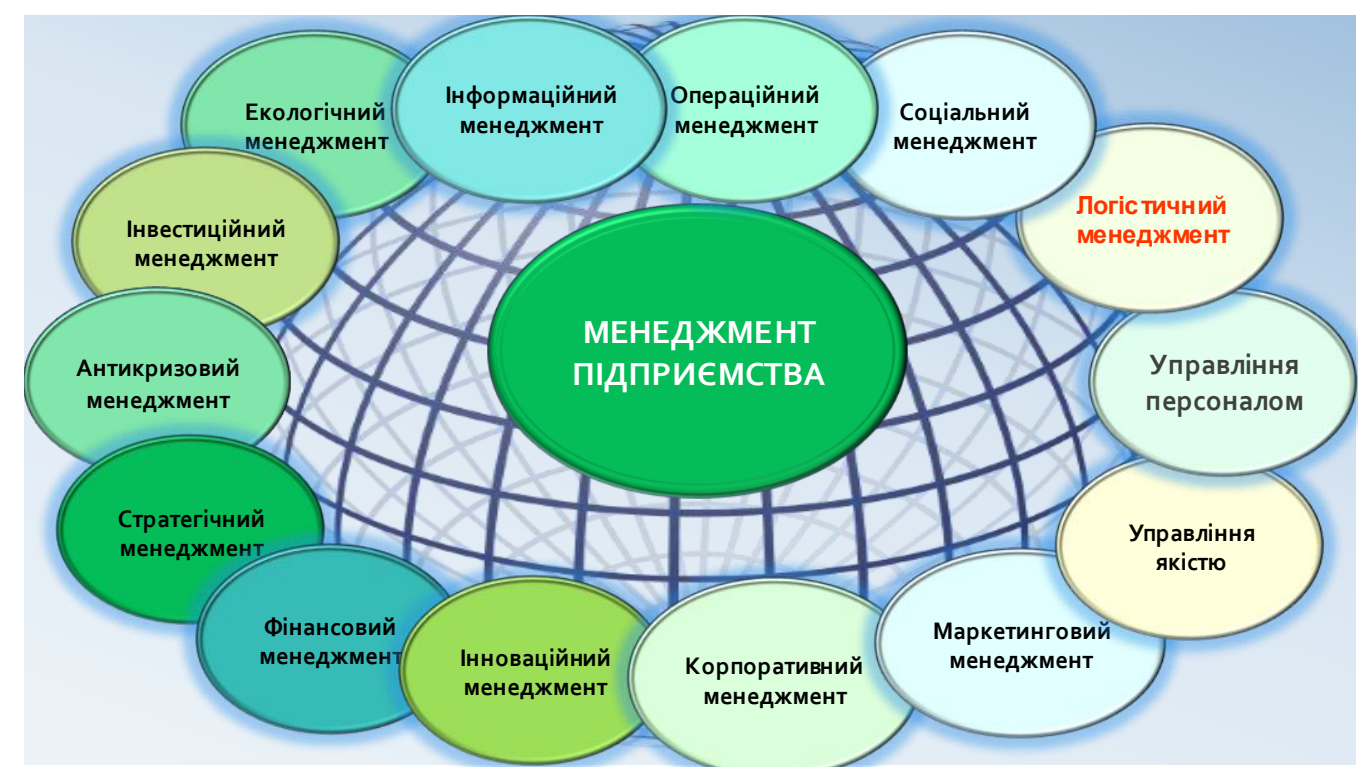

Рис. 1. Сучасна система менеджменту підприсмства* *розроблено авторами

Питаннями управління та оптимізації ресурсних потоків підприємства «опікується» логістичний менеджмент. Термін «логістичний менеджмент» трактується науковцями та практиками в різних аспектах. Так Д. Дж. Бауерокс, Д. Дж. Клосс у роботі «Логістика: інтегрований ланцюг постачання» визначають сутність логістичного менеджменту «у створенні й налагодженні таких систем управління потоками матеріальних ресурсів, незавершеного виробництва, запасів готової продукції, які були б опорою для розробки оптимальної ділової стратегії господарської одиниці» [9]. Із визначення витікає, що логістичний менеджмент виступає механізмом створення систем управління потоками ресурсів та запасів, автори відносять його до нижчої в ієрархії стратегій аніж ділова, тобто функціональної.

Представники логістичної школи НУ «Львівська політехніка» Є. Крикавський, Н Чухрай, Н. Чорнописька [10]. Надають наступне визначення дефініції «логістичний менеджмент» це - менеджмент у логістичних системах, який базується на теорії логіс- тики, а розуміння цього терміна «грунтується на інтеграції логістики та менеджменту у формі «логістикоменеджменту як комплексної локалізації систем управління матеріальними та інформаційними потоками»

3 точки зору Л. Ковальської «логістичний менеджмент - це сукупність функцій, методів та форм управління підприємством, реалізація яких спрямована на оптимізацію фінансових, матеріальних, інформаційних та інших потоків у межах логістичного ланцюга «постачання - виробництво - складування - збут» для забезпечення стійкого економічного зростання підприємства» [11]. 3 точки зору I. Смирнова «логістичний менеджмент займається вирішенням виробничих завдань шляхом планування i координації матеріального і пов'язаних із ним фінансових та інформаційних потоків упродовж усього логістичного ланцюга» [12]. Слід зазначити, що автор не надає логістичному менеджменту оптимізаційного характеру, що суперечить логістичному підходу. Поза увагою визначення залишилися завдання 
сервісного обслуговування.

В. Пономаренко, К. Таньков, Т. Лепейко виділяють наступні грані логістичного менеджменту «це функція органів управління спеціалізованих та інтегрованих організаційно-економічних систем 3 використанням логістичного підходу до доцільного й цілеспрямованого інтегрованого управління сукупністю внутрішніх та зовнішніх потокових процесів у визначених часових і просторових параметрах середовища сукупних виробничо-економічних відносин 3 метою отримання їх учасниками очікуваних конкурентних переваг і вигод» [13]. 3 визначення випливає, що логістичний менеджмент не $\epsilon$ функціональною областю менеджменту, а функцією органів управління - укрупненою групою логістичних операцій (логістичною функцією).

Автор даного дослідження визначає логістичний менеджмент, як функціонально-зорієнтовану область менеджменту, інструментарій логістики в управлінні та оптимізації потокових процесів з метою досягнення максимальної конкурентоспроможності підприємства. Виходячи з даного визначення максимальну конкурентоспроможність підприємства можна досягти за умов мінімізації логістичних витрат. У зв'язку з цим велика увага приділяється дослідженню сутності логістичних витрат, їх структури, шляхів оптимізації. Дані витрати забезпечують виконання логістичних операцій на стадіях обігу та організації виробництва і являють собою витрати з переміщення матеріальних, фінансових, інформаційних та інших ресурсів при виробництві готової продукції чи наданні послуг, величина яких залежить від об'єктивних (специфіки функціонування галузей національної економіки) та суб'єктивних (факторів організації логістики на підприємстві) чинників.

Л. Касьян вважає, що «логістичні витрати можна оцінити за місцем виникнення, носіями витрат, аналітичними рахунками витрат, за фазами логістичного процесу» [14]. Слушним є думка Я. Колодка, який стверджує, що «до складу логістичних витрат підприємства, окрім фактичних витрат, слід віднести втрати прибутку від іммобілізації оборотних коштів (виробничих запасів, незавершеного виробництва, готової продукції), збитки підприємства від невідповідного рівня якості ресурсів та готової продукції на всіх етапах проходження логістичного ланцюга - починаючи від постачання і закінчуючи розподілом продукції підприємства» [15]. Автор означив втрати прибутку від факторів, які можливо визначити 3 документів діяльності підприємства. Однак втрата прибутку можлива і від інших факторів, наприклад, не використання інноваційних рішень тощо.

Є. Крикавський вважає що логістичні витрати - це «сума витрат на управління та реалізацію логістичних процесів в окремих межах переміщення матеріальних потоків» [10]. О. Сумець визначає «...це витрати на виконання в логістичній системі усіх логістичних активностей, що пов'язані безпосередньо з логістичними потоками в межах визначеного простору і часу» [16].

На думку автора, логістичні витрати - це частина загальних витрат, понесених підприємством при логістичному забезпеченні створення цінностей у вигляді готової продукції чи послуги, і які покупець згоден і в змозі компенсувати через купівлю, вважаючи дану цінність для себе важливою.

Науковці та практики надають різні результати 3 дослідження ефективності застосування логістики в галузях народного господарства. Так у харчовій промисловості логістичні витрати складають біля 40 \% від загальних витрат, тоді як у машинобудуванні біля $10 \%$. Слід відмітити, що логістичні витрати мають тенденцію до зростання. Так А. Смехов надає такі пропорції: «питома вага адміністративноуправлінських витрат та обробки інформації складає 5-15\%; витрати перевезення на магістральному транспорті знаходиться в діапазоні від 28 до 40 \%; операції із складського зберігання та перевантаження складають 25-45 \%, операції з упакування складають 15$25 \%$, інші 5-17\%» [17].

О. Сумець в монографічному дослідження надає пропорції логістичних витрат одинадцяти олієекстрактних та олієжирових комбінатів України: постачання - 22,3\%, виробництво - 14,2 \%, дистрибуція - 36,9 \%, повернення браку - 4,9 \%, утилізація відходів - 11,2 \%, знищення відходів - 6,8 \%. При цьому максимальний розкид показників у діапазоні 54,4 \% спостерігається у межах функції розподіл та збут [16].

Величина логістичних витрат залежать також від видів перероблюваної сировини. Так в машинобудуванні витрати на внутрішньозаводське переміщення матеріальних ресурсів і доставку готової продукції споживачам складають 16,2 \%, витрати зберігання і формування запасів складають вище $35 \%$. В той час у харчових галузях внутрішньозаводське переміщення матеріальних ресурсів практично відсутнє, що пояснюється потоковими методами організації виробництва. Витрати зберігання і формування запасів у харчових галузях які переробляють швидкопсувну сировину, наприклад зелений горошок, такі запаси мінімальні і залежать від строків зберігання сировини.

Проаналізувавши результати представлених науковцями досліджень, слід зробити наступний висновок: дослідження здійснюються за різними структурами логістичних витрат, що по-перше, пояснюється відсутністю єдиної методики з дослідження означених витрат, по-друге, відсутністю відкритої інформації, щодо структури та величини логістичних витрат в галузях національної економіки. Управління та контроль за ефективністю проведення логістичних витрат можливе за умов наявності єдиної методики та єдиної класифікації за певними ознаками.

В рамках багатокритеріальної класифікації логістичних витрат олієдобувного підприємства виокремимо їх у дві групи та надано розгорнутий склад логістичних витрат:

- перша, яка включає витрати основних логістичних функцій: постачання, витрати виробництва та витрати дистрибуції;

друга - включає витрати допоміжних логістичних функцій: зберігання запасів, транспортування, утримання логістичної інфраструктури, утримання підсистеми інформаційного забезпечення. 
Склад логістичних витрат олісдобувного підприсмства за основними логістичними функціями [16]

\begin{tabular}{|l|l|}
\hline $\begin{array}{l}\text { Функціональні } \\
\text { області }\end{array}$ & \multicolumn{1}{c|}{ Логістичні витрати } \\
\hline Постачання & $\begin{array}{l}\text { моніторинг ринку закупівель; приймання продукції і підготовку ії до виробничого спо- } \\
\text { живання; затримки виробництва через збої у постачанні; утримання постачальницького } \\
\text { дання та оформлення замовлень, укладення договорів; підтримка контактів 3 постачаль- } \\
\text { никами; вибір і оцінка постачальників; контроль за виконанням умов договорів поста- } \\
\text { чання. }\end{array}$ \\
\hline $\begin{array}{l}\text { Організація та } \\
\text { управління } \\
\text { виробництва } \\
\text { олії }\end{array}$ & $\begin{array}{l}\text { конструкторська та технологічна підготовка виробництва; переналагодження устаткуван- } \\
\text { продукції; складання графіків виробництва; внутрішньовиробничі переміщення; вартість } \\
\text { бракованої продукції; видалення відходів та утилізація. }\end{array}$ \\
\hline Дистрибуція & $\begin{array}{l}\text { моніторинг споживчого ринку; опрацювання замовлень споживачів; підтримка контактів } \\
\text { зі споживачами; представницькі витрати та витрати з відряджень працівників збуту; } \\
\text { оплата послуг торгових посередників; передпродажний і післяпродажний сервіс; органі- } \\
\text { зація зворотних матеріальних потоків; штрафи споживачам за невчасне постачання про- } \\
\text { дукції; невиконання замовлень клієнтів. }\end{array}$ \\
\hline
\end{tabular}

Класифікація витрат за функціональними областями дає можливість розробки та застосування узагальнених методів оцінки логістичних витрат i методів їх оптимізації. 3 іншої точки зору, «логістичний менеджмент» виступає інструментарієм щодо оптимізації потокових процесів в окремих областях логістики. На рис. 2 представлено основні оптимізаційні рішення в окремих областях логістики.

До традиційного інструментарію логістичного управління потрібно віднести прийоми та спеціальні методи прийняття оптимальних логістичних рішень щодо об'єктів певної логістичної системи.

Приклади деяких із методів, їх сутність та сфери застосування.

1. Формула Вільсона - дає можливість розраховувати рівень запасів, здійснювати їх оптимізацію, здійснювати розрахунок розміру замовлень. Формула має множину модифікацій: модель 3 поступовим поповненням, модель з урахуванням втрат від дефіциту, модель роботи з багатономенклатурним замовленням, модель 3 урахуванням гуртових знижок, модель 3 урахуванням ПДВ.

2. Методи ABC-XYZ-аналіз є інструментами управління асортиментом масиву ресурсів. АВСаналіз визначає рейтинг ресурсів які забезпечують максимальний ефект. XYZ-аналіз - математикостатистичний метод дає змогу прогнозу стабільність продажів аналізованих ресурсів. Сумісне використання ABC-XYZ-аналізів дає більш точні результати за критеріями максимальний ефект, точність прогнозування продаж.

3. SWOT-аналіз - метод, який дає можливість аналізувати зовнішнє та внутрішнє середовищу підприємства. Стан зовнішнього середовища показують можливості та загрози. Сильні та слабкі сторони визначають внутрішній стан підприємства.

4. Аутсорсинг дослівно «запозичення ресурсів ззовні». Це передача на виконання не профільних для бізнесу організації завдань сторонньою організацією, яка для даної організації є профільною. В більшості передаються на аутсорсинг процеси: маркетингове дослідження, підбір та управління персоналом, програмне забезпечення, бухгалтерський облік, ремонт обладнання, господарські процеси, логістичні процеси (транспортування, складське зберігання, розмитнення товарів) та інші.

5. Концепція ланцюга вартості; це лінійно впорядкована множина постачальників, посередників, перевізників, регіональних терміналів, які забезпечують доведення продукції до кінцевого споживача.

6. Реінжиніринг логістичних процесів - інструмент досліджень та кардинальної оптимізації в рамках логістичних систем. В результаті реінжинірингу досягається суттєве поліпшення показників якості, логістичних витрат, обслуговування, швидкості.

Дії, щодо зниження рівнів логістичних витрат слід проводити за організаційними, технологічними та технічними напрямами базуючись на новітніх інноваційних розробках.

Організаційні напрями забезпечують високу ефективність за умов партнерської співпраці та включають задачі: оптимізації ланцюга поставок, пошуку та узгодження тривалості співпраці з постачальниками та потенціальними покупцями, узгодження рівнів і можливостей змін закупівельних цін та знижок, умов та графіків постачання, умов зберігання запасів, розподілу рисків та втрат при форс мажорних обставинах.

Технологічні та технічні напрями забезпечують зниження логістичних витрат в рамках границь логістичного циклу: в першу чергу, скорочення тривалості логістичного та технологічного циклу виробництва та дистрибуції готової продукції чи послуги за рахунок змін технологій та використовуваного технологічного, транспортного та складського обладнання. 


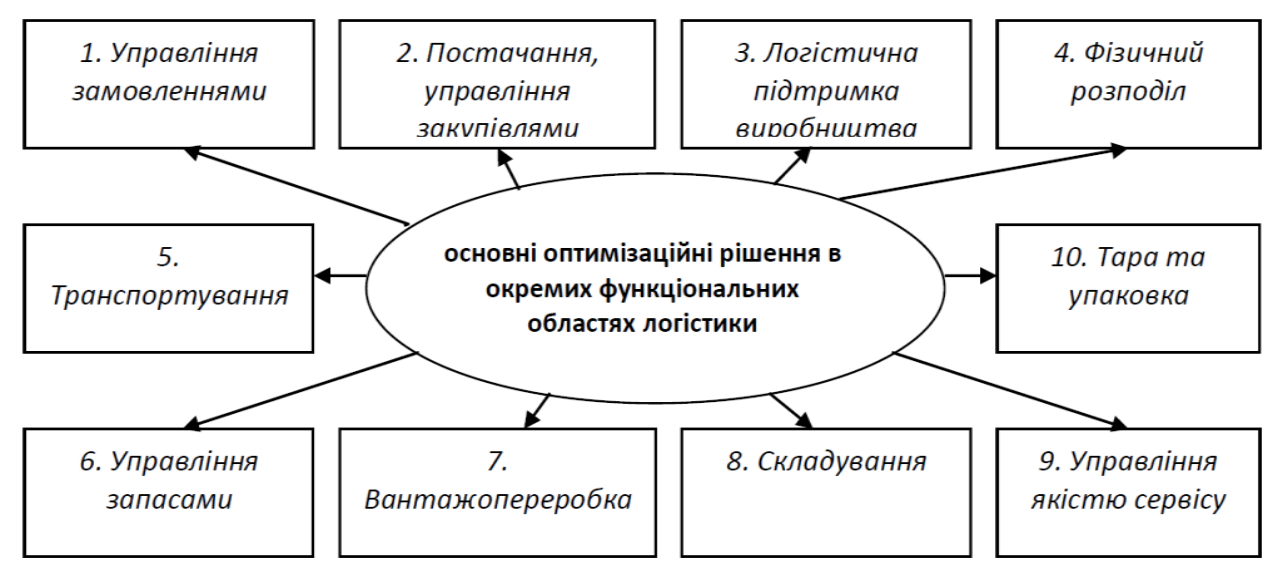

зміст задач оптимізації

1. детермінування циклу виконання замовлення (прийом, передача, обробка, комплектація, доставка); вибір технічних засобів і технологічного процесу виконання замовлення; організація документообігу та е-документообігу; оптимізація параметрів: якості логістичного сервісу, величини трансакційних витрат, параметрів післяпродажного сервісу.

2. вирішення завдання «зробити або купити»; вибір форми постачання підприємства; вибір постачальника; визначення потреби матеріальних ресурсів; оптимізація операційних логістичних витрат; мінімізація втрат продукції в процесі доставки від постачальників; структуризація логістичних каналів доставки; вибір стратегії закупівель; оптимізація запасів закуповуваної продукції на всіх рівнях логістичної системи.

3. оптимізація всіх рівнів запасів матеріальних ресурсів, незавершеного виробництва, готової продукції і складської системи підприємства; вибір оптимального режиму работи внутрішньовиробничого транспортно-складськаго комплексу; оптимізація часової структури виробничо-технологічнаго циклу; оптимізація операційних логістичних витрат у виробництві готової продукції; вибір внутрішньовиробничої інформаційної системи оптимізації ресурсів; вирішення проблеми відходів виробництва і ефективне використання вторинних матеріальних ресурсів і втрат від браку.

4. формування організаційної структури логістичних каналів і розподільчої мережі; оптимізація розташування регіональних розподільних центрів; вибір логістичних посередників; організація процесу складування; планування, контроль рівнів запасів готової продукції в розподільчої мережі, структуризація товарних потоків; координація та інтеграція взаємодії з логістичними посередниками; оптимізація логістичних витрат і ризиків при транспортуванні, складуванні і вантажопереробці; вибір системи моніторингу та інформаційно-комп'ютерної підтримки логістичних рішень; оптимізація параметрів фізичного розподілу товарних потоків в логістичних каналах.

5. вибір способу транспортування вантажів (унимодальный, мультимодальний, інтермодальний, змішаний, комбінований); вибір виду транспорту; вибір перевізника; оптимізація структури парку транспортних засобів; маршрутизація перевезень; визначення параметрів і методу оцінки транспортного сервісу; диспетчерування; планування собівартості перевезень та транспортних тарифів; розподіл прибутку, ризиків і відповідальності між учасниками транспортного процесу; планування потреби в матеріальних ресурсах для експлуатації, ремонту і обслуговування рухомого складу транспорту; планування інвестицій у виробничо-технічну базу транспорту; вибір системи фізичного супроводу та контролю місцезнаходження транспортного засобу та вантажу.

6. вибір: інтегрованої структури управління запасами; вибір критеріїв, стратегії управління запасами; методів прогнозування попиту на продукцію; систем обліку, контролю і моніторингу логістичних витрат управління запасами; систем контролю і управління запасами; визначення розміру, точки замовлення, інтервалу часу, кількості замовлень за плановий період; нормування та визначення рівнів поточного, страхового, сезонного, підготовчого запасу; оптимізація розміру замовлення; проведення аналізу ABC- XYZ-аналізу; вибір систем інформаційно-комп'ютерної підтримки управління запасами.

7. визначення параметрів матеріальних потоків і якості логістичного сервісу в вантажопереробці, операційних логістичних витрат; обгрунтування простору складування і переміщення вантажів; встановлення кількості, розміру або ваги оброблюваної партії вантажү; оптимізація рівня механізації і автоматизації операцій; уніфікація технологій вантажопереробки і рішення щодо використання стандартизованого устаткування; планування ремонту і забезпечення запасними частинами; планування інвестицій для заміни морально і фізично застарілого обладнання.

8. вибір системи складүвання, форми власності, типу, кількості та потужності складів; дислокація складів; визначення номенклатури та асортименту, що зберігається та обробляється на складі продукції; обгрунтування прийняпя проектних рішень складу; вибір логістичних посередників у складуванні; обгрунтування складу логістичних послуг та оцінка ї якості; визначення складського обладнання; встановлення параметрів транспортно-складського процесу 3 приймання, вантажопереробки і відправлення вантажів; обгрунтування обсягу логістичних витрат складування; вибір складських інформаційно-комп'ютерних систем.

9. вибір системи показників якості логістичного сервісу; вибір корпоративного управління якістю логістичного сервісу; вибір логістичних технологій, технічних засобів, систем і процедур забезпечення якості логістичного обслуговування; вибір методів моделей оцінки параметрів якості логістичного сервісу; вибір логістичних посередників; вибір комплексних моделей оцінки якості сервісу в логістичних системах.

10. рішення про дизайн тари і үпаковки відповідно до вимог логістичного менеджменту в процесі транспортування, складування і вантажопереробки; вибір тари і пакувальних матеріалів для різних класів вантажів; вибір тари, зовнішніх товароносіїв задля забезпечення транспортування і вантажопереробки; рішення щодо маркування та штрихового кодування тари, упаковки і вантажних одиниць.

Рис. 2. Основні оптимізаційні рішення в окремих областях логістики*

* розроблено авторами 
Висновки та перспективи подальших досліджень. Узагальнюючи результати дослідження автором надано власне бачення дефініцій логістика, логістичний менеджмент та логістичні витрати. Логістика - це науково-практичний напрям господарювання, сутність якого полягає в забезпеченні логістичних систем необхідними ресурсами за умов оптимізації витрат процесу переміщення ресурсних потоків в границях означених систем.

Авторське визначення поняттю логістичний менеджмент - це функціонально-зорієнтована область менеджменту, інструментарій логістики в управлінні та оптимізації потокових процесів 3 метою досягнення максимальної конкурентоспроможності підприємства.

Логістичні витрати - це частина загальних витрат, понесених підприємством при логістичному забезпеченні створення цінностей у вигляді готової продукції чи послуги, і які покупець згоден і в змозі компенсувати через купівлю, вважаючи дану цінність для себе важливою.

Доведено, що дії зниження рівнів логістичних витрат слід проводити за організаційними, технологічними та технічними напрямами базуючись на новітніх інноваційних розробках.

\section{Література}

1. Міжнародні логістичні асоціації: [інтернет-портал]. Одеса, 2018. URL: https://logistics-ukraine.com (дата звернення: 02.08.2020).

2. Аникин Б. А., Родкина Т. А. Логистика: учебное пособие. М: ТК Велки Проспект, 2008. 408 с.

3. Бажин И. И. Логистика: компакт-учебник: для студ. высших экон. учеб. заведХ: Коксум, 2014. 240 с.

4. Гаджинский А. М. Логистика: учебник. М: Дашков и К, 2016. 410 с.

5. Сергеев В. И. Логистика: учебник для бакалаврата и магистратуры. М: Юрайт, 2017. 542 с.

6. Седікова I. О. Формування організаційних структур управління на засадах логістики : автореф. дис. на здобуття наук. ступеня : канд. екон. наук : 08.00.04 : захист 08.12.2010 / наук. кер. И. И. Савенко. Харків: ХНАУ, 2010. $18 \mathrm{c}$.

7. Рада $з$ логістики США: [Веб-сайт]. Одеса, 2008. URL: https://www.clm.org (дата звернення: 02.08.2020)

8. Standartp 040805. ELA Certification for Logistics Professionalp. London, 2004. 15 p.

9. Бауэрсокс Д. Д., Клосс Д. Д. Логистика: интегрированая цепь поставок: учебник / пер. с англ. Н. Н. Барышниковой, Б. С. Пинскера. М: ЗАО «Олимп-Бизнес», 2008. 640 с.

10. Крикавський Є. Є., Чухрай Н. І., Чорнописька Н. В. Логістика: компендіум і практикум: навчальний посіб. К: Кондор, 2006. 340 с.

11. Ковальська Л. М., Циганюк В. П. Логістичний менеджмент на підприємстві: особливості та напрями вдосконалення // Зб. наук. праць / Луцький національний технічний університет. Луцьк, 2013. Т. 38, вип. 10. С. 87-97.

12. Смирнов І. К., Шматок О. В. Агрологістика в Україні: суспільно-географічні проблеми і перспективи розвитку // Економічна та соціальна географія. 2015. Т. 67, вип. 2. С. 96-109.

13. Понаморенко В. К. Логістичний менеджмент: підручник. Х: ІНЖЕК, 2010. 482 с. doi: $10.15216 / 9785406006481$

14. Касьян Л. С., Свіщов М. В. Аналіз впливу логістичних витрат на ефективність функціонування логістичної системи // Вісник КНУТ. 2013. Т. 2, вип. 1. С. 150-155.

15. Колодка Я. В. Особливості та оптимізація логістичних систем підприємств сільськогосподарської галузі // Інноваційна економіка. 2014. Т. 2, вип. 51. С. 131-136.

16. Сумець О. М. Логістичні витрати підприємств олійно-жирової галузі: формування та оцінювання: монографія. Х: Вид-во НУА, 2017. 243 с.

17. Смехов А. А. Логистика: учебник. М: Знание, 1998. 60 с.

Стаття надійшла 6.08.2020

Стаття прийнята до друку 20.08.2020

Доступно в мережі Internet 15.10.2020 


\section{Савенко И.И. \\ доктор экономических наук, профессор кафедра менеджмента и логистики \\ E-mail: iisavenko52@ukr.net \\ ORCID ID: 0000-0001-7901-6360 \\ Седиков Д.В. аспирант \\ кафедра менеджмента и логистики \\ Одесская национальная академия пищевых технологий ул. Канатная, 112, г. Одесса, Украина, 65039 \\ E-mail: sedikov94@ukr.net \\ ORCID ID: 0000-0001-7706-2881 \\ ЛОГИСТИЧЕСКИЙ МЕНЕДЖМЕНТ КАК ИНСТРУМЕНТАРИЙ ОПТИМИЗАЦИИ ЛОГИСТИЧЕСКИХ ЗАТРАТ}

Конкурентоспособность предприятий выступает ключевым фактором выживания и дальнейшего их развития в условиях жёсткой рыночной экономики. Обеспечение эффективного уровня конкурентоспособности достигается различными методами и приёмами организационного, технологического и технического характера. В перечне эффективных методов и приёмов важное место занимает логистика, как прогрессивное направление хозяйствования.

Статья посвящена исследованию влияния логистики на конкурентоспособность предприятий, влиянию логистического менеджмента, как инструментария логистики, на оптимизацию логистических затрат, влиянию логистических затрат на формирование себестоимости продукции и путей их сокращения.

Несмотря на трансорормации, которые протекают в обществе (переход к постиндустриализму), эффрективных инструментов менеджмента предприятий как логистический подход, наука и практика не разработала.

Обобщая результаты исследования, автором предложено собственное видение дефиниций «логистика», «логистический менеджмент», «логистические затраты».

Логистика - это научно-практическое направление хозяйствования, сущность которого состоит в обеспечении логистических систем необходимыми ресурсами при условии оптимизации затрат при перемещении ресурсных потоков в границах определённых систем.

Логистический менеджмент - это функционально-ориентированная область менеджмента, инструментарий логистики в управлении и оптимизации поточных процессов с целью достижения максимальной конкурентоспособности предприятия.

Логистические затраты - это часть общих затрат, понесенных предприятием при логистическом обеспечении создания ценностей в виде готовой продукции или услуги, и которые покупатель согласен компенсировать при покупке, считая эту ценность важной для себя.

Доказано, что работа по снижения уровней логистических затрат следует осуществлять посредством организационных, технологических технических мероприятий базируясь на новых инновационных разработках.

Ключевые слова: логистика, логистический менеджмент, логистические затраты, функциональные области логистики.

\section{Savenko I.}

Doctor of Economics, Professor

Department of Management and Logistics

E-mail: iisavenko52@ukr.net

ORCID ID: 0000-0001-7901-6360

Sedikov D.

Postgraduate student

Department of Management and Logistics

Odessa National Academy of Food Technologies

Kanatna str., 112, Odesa, Ukraine, 65039

E-mail: sedikov94@ukr.net

ORCID ID: 0000-0001-7706-2881

\section{LOGISTICS MANAGEMENT AS A TOOL FOR OPTIMIZING LOGISTICS COSTS}

The competitiveness of enterprises is a key factor in their survival and their further development in the conditions of a tough market economy. Ensuring an effective level of competitiveness is achieved by var- 
ious methods and techniques of an organizational, technological and technical nature. In the list of effective methods and techniques, logistics occupies an important place as a progressive direction of management.

The article is devoted to the study of the influence of logistics on the competitiveness of enterprises, the influence of logistics management as a logistics toolkit on the optimization of logistics costs, the influence of logistics costs on the formation of production costs and ways to reduce them.

Despite the transformations that are taking place in the society (the transition to post-industrialism), science and practice have not developed effective tools for enterprise management such as a logistic approach.

Summarizing the results of the study, the author proposed his own vision of the definitions of "logistics", "logistics management", "logistics costs".

Logistics is a scientific and practical direction of management, the essence of which is to provide logistics systems with the necessary resources, subject to cost optimization when moving resource flows within the boundaries of certain systems.

Logistics management is a functionally oriented area of management, a logistics toolkit in the management and optimization of flow processes in order to achieve maximum competitiveness of the enterprise.

Logistics costs are a part of the total costs incurred by the enterprise in the logistics of creating value in the form of a finished product or service, and which the buyer agrees to compensate when purchasing, considering this value to be important to himself.

It has been proved that the work to reduce the levels of logistics costs should be carried out through organizational, technological and technical measures based on new innovative developments.

Keywords: logistics, logistics management, logistics costs, functional areas of logistics.

\section{References}

1. Mizhnarodni lohistychni asotsiatsii. (2018). Retrieved August 2, 2020, from https://logistics-ukraine.com

2. Anikin, B. A., \& Rodkina, T. A. (2008). Logistika. B. A. Anikin \& T. Rodkina (Eds.). AM: TK Velki Prospekt.

3. Bazhin, I. I. (2014). Logistika. H.: Koksum.

4. Gadzhinskiy, A. M. (2016). Logistika. Moscow: Dashkovi K.

5. Sergeev, V. I. (2017). Logistika. Moscow: Yurayt.

6. Sedikova, I. O. (2010). Formuvannia orhanizatsiinykh struktur upravlinnia na zasadakh lohistyky (avtoref. dissertation of ekon. nauk: 08.00.04). Kharkiv: KhNAU.

7. Rada z lohistyky SShA. (2008). Retrieved August 2, 2020, from https://www.clm.org

8. Standartp 040805 (2004). ELA Certification for Logistics Professionalp. London.

9. Bauersoks, D. D., \& Kloss, D. D. (2008). Logistika (N. N. Baryishnikovoy, \& B. S. Pinskera, Trans.). Moscow: ZAO «Olimp-Biznes».

10. Krykavskyi, Ye. Ye., Chukhrai, N. I., \& Chornopyska, N. V. (2006). Lohistyka: kompendium i praktykum. Kyiv: Kondor.

11. Kovalska, L. M., \& Tsyhaniuk, V. P. (2013). Lohistychnyi menedzhment na pidpryiemstvi: osoblyvosti ta napriamy vdoskonalennia. Zb. nauk. Prats Lutskyi natsionalnyi tekhnichnyi universytet, 38(10), 87-97.

12. Smyrnov, I. K., \& Shmatok, O. V. (2015). Ahrolohistyka v Ukraini: suspilno-heohrafichni problemy i perspektyvy rozvytku. Ekonomichna ta sotsialna heohrafiia, 67(2), 96-109.

13. Ponamorenko, V. K. (2010). Lohistychnyi menedzhment. Kh: INZhEK. doi: 10.15216/9785406006481

14. Kasian, L. Ye., \& Svishchov, M. V. (2013). Analiz vplyvu lohistychnykh vytrat na efektyvnist funktsionuvannia lohistychnoi systemy. Visnyk KNUT, 2(1), 150-155.

15. Kolodka, Ya. V. (2014). Osoblyvosti ta optymizatsiia lohistychnykh system pidpryiemstv silskohospodarskoi haluzi. Innovatsiina ekonomika, 2(51), 131-136.

16. Sumets, O. M. (2017). Lohistychni vytraty pidpryiemstv oliino-zhyrovoi haluzi: formuvannia ta otsiniuvannia. Kh: Vyd-vo NUA

17. Smehov, A. A. (1998). Logistika. Moscow: Znanie

Received 6 August 2020

Approved 20 August 2020

Available in Internet 15.10.20

Цитування згідно ДСТУ 8302:2015

Савенко І.І., Седіков Д.В. Логістичний менеджмент, як інструмент оптимізації логістичних витрат // Економіка харчової промисловості. 2020. Т.12, вип. 3. С. 42-50. doi: 10.15673/fie.v12i3.1815

Cite as APA style citation

Savenko, I., \& Sedikov, D. (2020). Logistics management as a tool for optimizing logistics costs. Food Industry Economics, 12(3), 42-50. doi: 10.15673/fie.v12i3.1815 